\title{
Effect Of Health Education About Snack Foods On Snack Food Preferences In Elementary School Students At SdnJagir 1/393 Surabaya
}

\author{
Eppy Setiyowati ${ }^{1}$, Selvya Alamsyah ${ }^{2}$ \\ ${ }^{1,2}$ Faculty of Nursing and Midwifery, Surabaya Nahdlatul Ulama University \\ Email: eppy@unusa.ac.id
}

\begin{abstract}
Abstrak
Makanan jajanan merupakan jenis jajanan yang sangat disukai anak sekolah dan sulit untuk dipisahkan. Anak-anak sekolah biasa membeli makanan jajanan tanpa memperdulikan kandungan gizinya. Kesukaan anak yang berlebihan terhadap jajanan dapat menimbulkan dampak negatif seperti nafsu makan menurun dan menimbulkan berbagai macam penyakit akibat makanan yang kurang higienis. Tujuan penelitian menganalisis pengaruh pendidikan kesehatan tentang makanan jajanan terhadap kesukaan (preferensi) makanan jajanan pada siswa SD di SDN Jagir 1/393 Surabaya. Desain penelitian Pra-Experiment dengan pendekatan one group pre-post test design. Jumlah sampel sebesar 70 siswa terdiri dari kelas 4, 5 dan 6. Pengambilan sampel dengan menggunakan probability sampling dengan teknik stratified random sampling dan menggunakan kuesioner sebagai alat ukur. Data dianalisis menggunakan uji Paired T-Test dengan tingkat signifikansi 0,05. Hasil penelitian dengan menggunakan uji Paired T-Test didapatkan nilai $\rho=0,000$ dengan tingkat kemaknaan $\alpha=0,05$ berarti $\rho<\alpha$, maka $\mathrm{H}_{0}$ ditolak dan $\mathrm{H}_{1}$ diterima yang artinya ada pengaruh pendidikan kesehatan tentang makanan jajanan terhadap kesukaan (preferensi) makanan jajanan pada siswa SD di SDN Jagir 1/393 Surabaya. Simpulan dari penelitian ini adalah pendidikan kesehatan memberikan pengaruh pada siswa SD terhadap kesukaan makanan jajanan. Saran, bagi pihak sekolah agar menjadi bahan pertimbangan dalam meningkatkan pengetahuan siswa dalam memilih makanan jajanan yang sehat, aman dan bernutrisi.
\end{abstract}

Kata kunci: pendidikan kesehatan, preferensi, makanan jajanan

\begin{abstract}
Snack food is a type of snack that is very popular with school children and is difficult to separate. School children usually buy snacks without considering their nutritional content. Excessive children's preference for snacks can have a negative impact such as decreased appetite and cause various kinds of diseases due to less hygienic food. The study aimed to analyze the effect of health education on snack foods on the preferences (preferences) of snack foods on elementary students at Jagir Elementary School 1/393 Surabaya.Pre-Experimental research design with one group pre-post test design approach. The number of samples is 70 students consisting of grades 4, 5 and 6. Sampling using probability sampling with stratified random sampling technique and using a questionnaire as a measuring instrument. Data were analyzed using Paired T-Test with a significance level of 0.05. The results of the study using Paired $T$-Test obtained a value of $\rho=0,000$ with a significance level of $\alpha=0.05$ means $\rho<\alpha$, then $\mathrm{HO}$ is rejected and $\mathrm{H} 1$ is accepted which means that there is an influence of health education on snack foods on snack food preferences elementary school students at SDN Jagir 1/393 Surabaya. This study concludes that health education has an effect on elementary students on the preference of snack foods. Suggestions, for the school, to be taken into consideration in increasing students' knowledge in choosing healthy, safe and nutritious snacks.
\end{abstract}

Keywords: health education, preference, snack food 
Article info:

Article submitted on September 06, 2019

Articles revised on September 14, 2019

Articles received on November 18, 2019

DOI: http://dx.doi.org/10.21927/jnki.2019.7(3).146-152

\section{INTRODUCTION}

Snack food is a type of snack that is very popular with school children and is difficult to separate, both in the home environment and at school they are always surrounded by vendors of snacks. The food offered by snack sellers is not necessarily healthy, because some of them pay less attention to cleanliness, food safety, and available nutritional content. School children usually buy snacks without considering their nutritional content, regardless of whether the snacks are healthy or not, contain preservatives, dangerous dyes, use artificial sweeteners, and contain excessive flavoring.

The choice of foods that are formed early will still affect their food preferences as adults. Excessive children's preference for snacks can have a negative impact such as decreased appetite and cause various kinds of diseases due to less hygienic food. Such joy can also cause the nutritional needs of school children not to be fulfilled if the food is not balanced. Based on Hastutic research (2018), it showed that the majority of students liked the type of snack food in the form of batagor, somay, fried food, cimol, and cilok as many as 17 students (60.7\%). In the study of AisyiyatunSholehah (2016), it was found that students who did not like fruits and vegetables were $(77.3 \%)$.

Another study conducted by LeilyAmalia (2012), in all snack groups, a minimum of $60 \%$ of subjects made taste as the main reason for enjoying snacks, followed by prices (6\% - 27\%). Very few subjects make nutritional aspects of the reason for liking and choosing snacks (0-6\%). Based on the results of a preliminary survey conducted by researchers at SDN Jagir 1/393
Surabaya on October 9, 2018, that the school did not have a canteen there was only a school cooperative that sold school supplies. Outside of school, there are many kinds of snacks sellers such as pentol, cimol, papeda, various ice, sempol, and others. Of the 10 students who filled out the initial data questionnaire, they all said they bought snacks that were sold in front of the school. The snacks they often buy vary, 5 out of 10 students say they often buy papeda snacks, and 5 other students often buy cider bread, sweets, ice cream, crab sticks, and tea drinks and almost all the snacks they buy are all wrapped with plastic.

Child's preferences are influenced by individual characteristics including age, gender, and pocket money. Other characteristics that influence children's eating preferences are food characteristics which include taste, color, and price. Family characteristics also influence children's eating preferences which include family income, family size, and parental education. Besides individual characteristics, food, and family, the characteristics of the school environment also influence children's eating preferences (15).

Providing education as early as possible is one way to increase one's knowledge. Therefore, we need a media that can increase the effectiveness of the health education process, such as posters, leaflets, food models, brochures, videos, slides, flipcharts, and others. Based on the description above, the researcher was interested in examining the effect of health education on snack foods on the preferences of snack foods for elementary students at SDN Jagir 1/393 Surabaya. 
The general objective of this study was to analyze the effect of health education on snack foods on the preferences (preferences) of snack foods on elementary students at SDN Jagir 1/393 Surabaya. The specific objective of this study was to identify snacks (preferences) before and after being given health education about snacks for elementary students at Jagir Elementary School 1/393 Surabaya.

\section{MATERIALS AND METHODS}

This study used Pre-Experiment research with a one-group pre-post test design approach. The population in this study were all students of grade 4, 5, 6 SDN Jagir 1/393 Surabaya which amounted to 250 people. Sampling in this study is to use probability sampling with a stratified random sampling technique. The sample size used as respondents in the study was 70 students of grades 4, 5 and 6 of SDN Jagir 1/393 Surabaya. Post-Experiment research with the design approach, The population in this study were all students of grade 4, 5, 6 SDN Jagir 1/393 Surabaya which amounted to 250 people. Sampling in this study is to use probability sampling with a stratified random sampling technique. The sample size used as respondents in the study was 70 students of grade 4,5 and 6 of SDN Jagir 1/393 Surabaya

The independent variable in this study is health education about snack foods. The dependent variable is the preference for snacks. Categories and criteria for health education variables about snack foods using SAP and favorite variables (preferences) using scores, for healthy snacks, really like: score 2, like: score 1, dislike: score 0 . Unhealthy snacks really like: score 0 , likes: score 1 , dislikes: score 2 . favorite category of street food: does not like snacks with a value of 0 -22.7, likes snacks with a value of 23.7 - 46.4, really likes snacks with a value of 47, 4 - 68. The collected data is then processed with the technique of Editing, Coding, Scoring,
Processing, Cleaning, Tabulating, after that it is analyzed using paired T-test and before analyzing use normality test with a significance level of $\alpha=0.05$.

\section{RESULTS AND DISCUSSION}

Table 1 shows that out of 70 respondents almost half $(41.4 \%)$ are 11 years old. The results of the pre-test answers obtained showed that 11 -year-olds entered the category of snack foods. This is because school-age children spend most of their time in school environments so that children will have greater potential to get food from outside the home, one of which can be obtained through street food sold in general. Wong (2009) states that school age is a child at the age of 6-12 years, whereas in Indonesia it is usually a child aged 7-12 years, which means that school is a core experience for children. Febriani (2018), states that age factors influence children's knowledge based on the age, maturity, and strength of a person will be more mature in thinking so they can choose snacks that are clean or not clean.

Table 1. Frequency Distribution of Respondents by Age at Students of SDN Jagir 1/393 Surabaya

\begin{tabular}{ccc}
\hline Age (years) & Frequency $(\mathrm{n})$ & Percent $(\%)$ \\
\hline 10 & 16 & 22,9 \\
11 & 29 & 41,4 \\
12 & 20 & 28,6 \\
13 & 5 & 7,1 \\
\hline Total & 70 & $100 \%$ \\
\hline
\end{tabular}

Source: Primary data, May 2019

Table 2 shows that out of 70 respondents, almost half $(34.4 \%)$ of class 5 respondents.

The knowledge given early will continue to be brought to old age, the higher the class, the more knowledge will also increase. If one's knowledge is getting better and more numerous, then a person's attitude and behavior can improve, because good behavior comes from good knowledge. Nursani (2017), states that grades 5 and 6 are included in the formal operational stage. The formal operational stage 
is the last period of cognitive development in Piaget's theory. At this stage students have been able to think abstractly, reason logically, and be able to conclude from information that has been given so that the knowledge gained will be better, then attitudes and behavior will also be better.

Table 2. Frequency Distribution of Respondents by Class in Students of SDN Jagir 1/393 Surabaya

\begin{tabular}{ccc}
\hline Class (SD) & Frequency $(\mathrm{n})$ & Percent (\%) \\
\hline 4 & 22 & 31.4 \\
5 & 24 & 34.3 \\
6 & 24 & 34.3 \\
\hline Total & 70 & $100 \%$ \\
\hline
\end{tabular}

Source: Primary data, May 2019

Table 3 shows that of the 70 respondents most $(65.7 \%)$ were female. Gender plays an important role as a determinant of food selection and determines the type of food eaten is classified as healthy or not. Oktavianus (2013), states that women are mainly due to gender roles that have historically persisted in modern society (shopping and cooking) tend to be more involved in food than men.

Table 3. Distribution of Frequency of Respondents by Gender in Students of SDN Jagir 1/393 Surabaya.

\begin{tabular}{lcc}
\hline \multicolumn{1}{c}{ Gender } & Frequency $(\mathrm{n})$ & Percent $(\%)$ \\
\hline Male & 24 & 34.3 \\
Female & 46 & 65.7 \\
\hline \multicolumn{1}{c}{ Total } & 70 & $100 \%$ \\
\hline
\end{tabular}

Source: Primary data, May 2019

Table 4 shows that out of 70 respondents most $(61.4 \%)$ like snacks. The pre-test results of snack food preferences obtained showed for the dislike category of 5 respondents, the likes category of 43 respondents, and the very like category of 22 respondents. Snacks are commonplace for school children. In one aspect the snack has a positive aspect and in the other aspect has a negative aspect. The range between breakfast and lunch is relatively long so school children need additional nutritional intake between the two meals. Syarifah (2010), states that the consumption of snacks for children can contribute $30 \%$ and $22.3 \%$ to the adequacy of energy and protein.

Table 4. Respondent Frequency Distribution Based on Pre Test Results of Preference (Preference) for Snack Food in Students of SDN Jagir 1/393 Surabaya

\begin{tabular}{lcc}
\hline Levels of Preference & Frequency $(\mathrm{n})$ & Percent $(\%)$ \\
\hline Dislike & 5 & 7,1 \\
Like & 43 & 61,4 \\
Really like & 22 & 31,4 \\
\hline \multicolumn{1}{c}{ Total } & 70 & $100 \%$ \\
\hline
\end{tabular}

Source: Primary data, May 2019

Table 5 shows that out of 70 respondents most $(58.6 \%)$ like healthy snacks. The results of the pre-test for healthy and unhealthy snacks obtained showed that there were 29 respondents for unhealthy snacks, and 41 healthy respondents for healthy snacks. The healthy snacks they like are meatball (70.0\%), potato donuts (68.6) and a watermelon (37.1). Unhealthy snacks such as green bean \& black sticky rice porridge (38.6\%), pukis cake $(31.4 \%)$, and pineapple fruit $(74.3 \%)$. This can be seen from the results of interviews with several students that some of them claimed to buy snacks to fill their stomachs because they were hungry at rest. Hastutik (2018), states that snack foods can supplement and increase one's nutritional adequacy if the food consumed is guaranteed to have cleanliness and nutritional content.

Table 5. Distribution of Respondents Based on PreSnack Pre-Test Results Healthy and unhealthy for Jagir 1/393 SDN Students

\begin{tabular}{ccc}
\hline \multicolumn{1}{c}{ Type Snack } & Frequency $(\mathrm{n})$ & Percent $(\%)$ \\
\hline Unhealthy & 29 & 41,4 \\
Healthy & 41 & 58,6 \\
\hline Total & 70 & $100 \%$ \\
\hline
\end{tabular}

Source: Primary data, May 2019

Table 6 shows that out of 70 respondents most $(65.7 \%)$ like snacks. The post-test results of snacks for snacks showed 12 categories of dislikes, 46 respondents liked and 12 respondents liked very much. There is an increase in the 
number of respondents who do not like street food, which means students have begun to understand and practice good behavior activities such as choosing and eating healthy snacks. Purnomo (2010) states that good behavior if a person can do behavior towards food and drink, behavior towards personal hygiene and behavior towards environmental cleanliness.

Table 6. Respondent Frequency Distribution Based on the Results of Favorite Post Test (Preference) for Student Snack Foods at Jagir Elementary School $1 / 393$ Surabaya

\begin{tabular}{lcc}
\hline Levels of Preference & Frekuensi $(\mathrm{n})$ & Percentage (\%) \\
\hline Dislike & 12 & 17,1 \\
Like & 46 & 65,7 \\
Really like & 12 & 17,1 \\
\hline \multicolumn{1}{c}{ Total } & 70 & $100 \%$ \\
\hline
\end{tabular}

Source: Primary data, May 2019

Table 7 shows that out of 70 respondents most (74.3) like healthy snacks. The results of the post-test for healthy and unhealthy snacks obtained showed that for 18 unhealthy snacks, there were 52 respondents for healthy snacks. There is an increase in the number of respondents who like healthy snacks, this can be seen from the results of interviews with several students, some of them said they always had breakfast before going to school and there were students who brought lunch from home so they did not often buy snacks outside the school when recess. Even though two weeks they want to buy snacks, they prefer to buy filling snacks such as bread. Hastutik (2018), states that the provision of food prepared from home will be more easily monitored for its nutritional content, hygiene, and cleanliness, and can avoid children's habits for snacks at school.

Table 7. Distribution of Respondents Based on the Results of Post Tests for Healthy and Unhealthy Snacks on Students of SDN Jagir 1/393 Surabaya

\begin{tabular}{ccc}
\hline Type Snack & Frequency $(\mathrm{n})$ & Percent $(\%)$ \\
\hline Unhealthy & 18 & 25,7 \\
Healthy & 52 & 74,3 \\
\hline Total & 70 & $100 \%$ \\
\hline
\end{tabular}

Source: Primary data, May 2019
Table 8 shows that out of 70 pre-test respondents given health education about snack foods, the results obtained for the dislike category were 5 respondents, the category of the likes was 43 respondents, and the very like category was 22 respondents. The post-test results showed 12 categories of dislikes, 46 respondents liked and 12 respondents liked very much. These results indicate that there is an increase in the number of respondents in the category of dislike of 7 respondents, an increase in the number of respondents in the category of the likes of 3 respondents, and a decrease in the number of respondents in the very like category of 10 respondents. These changes are the result of health education that has been given. Kindi Amelia (2013), states that the higher the level of knowledge of food and health, the lower the frequency of consumption of snacks for elementary school children.

The statistical test of the Paired T-test in table 5.6 shows the value of $\rho=0,000$ with a significance level of $\alpha=0.05$. So $\rho<\alpha$, then $\mathrm{HO}$ is rejected and $\mathrm{H} 1$ is accepted, which means that there is an influence of health education on snack foods on the preferences (preferences) of snack foods for elementary students at SDN Jagir 1/393 Surabaya. The contingency coefficient showed that 0.669 showed that the influence of health education on the preferences of snacks was very strong.

Table 8. Distribution of Differences in Preference (Preference) for Snack Food Pre-test and Post-test Provided Health Education for Students at SDN Jagir 1/393 Surabaya

\begin{tabular}{lcccc}
\hline \multirow{2}{*}{ Pre Test } & \multicolumn{3}{c}{ Post Test } & \multirow{2}{*}{ Total } \\
\cline { 2 - 4 } & Dislike & Like & Really Like & \\
\hline Dislike & 5 & 0 & 0 & 5 \\
Like & 7 & 36 & 0 & 43 \\
Really Like & 0 & 10 & 12 & 22 \\
\hline Total & 12 & 46 & 12 & 70 \\
\hline Statistic test Paired T-test & & \\
P-value Sig. (2-tailed) $=0,000$ & & \\
Contingency Coefficient $=0,669$ & & \\
\hline
\end{tabular}

Source: Primary data, May 2019 


\section{CONCLUSION AND RECOMMENDATION}

Elementary students at Jagir Elementary School 1/393 Surabaya before being given health education about snack foods on the preference of snack foods showed that of the 70 respondents most of them liked snacks. Elementary students at Jagir Elementary School 1/393 Surabaya after being given health education about snack foods on the preferences of snack foods showed that of the 70 respondents most of them liked snack foods with a percentage increase. There is the influence of health education about snack foods on the preferences (preferences) of snack foods for elementary students at SDN Jagir 1/393 Surabaya. For Respondents, it is expected that by giving health education about snack foods to the preferences (preferences) of snack foods, students can understand and understand the importance of healthy and unhealthy snacks, and can apply to be more selective in buying snacks. For Research Sites, it is expected that the school can guide students to be more careful in buying snacks and considerations for the school in increasing students' knowledge in choosing healthy, safe and nutritious snacks.

\section{REFERENCES}

1. Amelia, Kindi, Yuliana, dan Kasmita. 2018. Hubungan Pengetahuan Makanan Dan Kesehatan Dengan Frekuensi Konsumsi Makanan Jajanan Pada Anak Sekolah Dasar Pembangunan Laboratorium Universitas Negeri Padang. Program Studi Pendidikan Kesejahteraan Keluarga Fakultas Teknik Universitas Negeri Padang.

2. Febriani, Kiki, Erlisa Candrawati, Ronasari Mahaji Putri. 2018. Pengaruh Pendidikan Kesehatan Terhadap Peningkatan Pengetahuan Dalam Pemilihan Jajan Pada Anak Usia Sekolah 7-9 Tahun Desa Ngantru Kecamatan Ngantang Kabupaten Malang. Nursing New, vol. 3(1) 481-491.
3. Fikawati, Sandra, Ahmad Syafiq, dan Arinda Veratamala. 2017. Gizi Anak dan Remaja. Depok: Rajawali Pers.

4. Fitriani, P. 2015. Ilmu Gizi Pada Anak. Jakarta: Fakultas Kedokteran Universitas Indonesia.

5. Fitriani, Sinta. 2011. Promosi Kesehatan. Yogyakarta: Graha IImu.

6. Hastutik, dan N.Kadek Sri EkaPutri. 2018. Deskripsi Kebiasaan Jajan Pada Anak Sekolah Dasar Negeri 03 Kragilan Mojolaban Sukoharjo. Jurnal IImu Keperawatan dan Kebidanan, vol. 9(2) : 162-167.

7. Herlina. 2013. Bibliotherapy: Mengatasi Masalah Anak Dan Remaja Melalui Buku. Bandung: PustakaCendekiaUtama.

8. Induniasih dan Wahyu Ratna. 2017. Promosi Kesehatan: Pendidikan Kesehatan dalam Keperawatan. Yogyakarta: Pustaka Baru Press.

9. Kurnia Noviani, Effatul Afifah, Dewi Astiti, 2016 Kebiasaan jajan dan pola makan serta hubungannya dengan status gizi anak usia sekolah di sd sonosewu bantul Yogyakarta, Jurnal Gizi Dan Dietetik Indonesia Vol. 4 No 2 Mei 2016 .

10. Masta Hutasoit, Latifah Susilowati. 2018. Relationship Between Nutritional Status And Classification For Cough Or Difficult Breathing Of Children Under Five Years In Community Health Center Of Piyungan Bantul Yogyakarta. JNKI, Vol. 6, No. 3, Tahun 2018, 232-239

11. Niman, Susanti. 2017. Promosi dan Pendidikan Kesehatan. Jakarta: Trans Info Media.

12. Nurbiyati, Titik dan Agus Hindarto Wibowo. 2014. Pentingnya Memilih Jajanan Sehat Demi Kesehatan Anak. Jurnal Inovasi dan Kewirausahaan, vol. 3(3) : 192-196 ISSN: 2089-3086.

13. Nursalam. 2017. Metodologi Penelitian IImu Keperawatan: Pendekatan Praktis, edisi 4. Jakarta: Salemba Medika. 
14. Nursani, Arina Muthia. 2017. Faktor-faktor yang Berhubungan dengan Preferensi Sayur pada Siswa-Siswi Kelas 4 dan 5 Madrasah Ibtidaiyah Pembangunan UIN Jakarta. Skripsi. Program Studi Kesehatan Masyarakat FKIK UIN syarif Hidayatullah Jakarta.

15. Permana, Endah Budi, Sumarni, dan Fatma Zuhrotun Nisa. 2019. Faktor Yang Berhubungan Dengan Preferensi Konsumen Street Food Pada Mahasiswa Universitas Gadjah Mada. Jurnal Gizi Dan Dietetik Indonesia, vol. 3(3) : 131-138

16. Purtiantini. 2012. Berbagai Cara Pendidikan Gizi. Jakarta: Bumi Aksara.

17. Shewfelt, Robert L. 2013. Pengantar IImu Pangan. Jakarta: EGC.

18. Siti Nurunniyah, Eka Surasa, Zulpahiyana. 2018. The Level of Education and Knowledge
Associated with Complience of Health Care Workers for Triage Implementation, JNKI, Vol. 6, No. 1, Tahun 2018, 78-84.

19. Soekidjo, Notoatmodjo. 2012. Metodologi Penelitian Kesehatan. Jakarta: Rineka Cipta. 20. Susilo, Rakhmat. 2011. Pendidikan Kesehatan dalam Keperawatan. Yogyakarta: Nuha Medika.

21. Syarifah. 2010. Kebiasaan Jajan Serta Kontribusi Energi dan Zat Gizi Makanan Jajanan Terhadap Kecukupan Gizi Siswa Sekolah Dasar (Skripsi). Mayor Ilmu Gizi Departemen Gizi Masyarakat. Fakultas Ekologi Manusia. Institusi Pertanian Bogor. 22. Wong, L. 2009. Buku Ajar Keperawatan Pediatrik Volume 2. Jakarta: EGC 